\title{
Effect of FYM on Growth, Yield and Fruits Quality of Okra) Abelmoschus Esculentus. L Moench)
}

\author{
Hisham Aziz Amran ${ }^{1}$, V. M. Prasad ${ }^{2}$ \& S. Saravanan ${ }^{3}$ \\ 1Iraqi Ministry of Higher Education, University of Karbala, Collage of Agriculture \\ ${ }^{2,3}$ Department of Horticulture a, College of Agriculture, University of SHIATS, Naini, \\ Allahabad, Uttar Pradesh, India
}

\begin{abstract}
The experiment was carried out in vegetable Research Farm, during ninth of February to tenth of May in 2013 with following combination of which was $T 1$ ( $V_{l}$ ( NOH-15) without FYM), $T_{2}\left(V_{l}\right.$ (NOH-15) +Farm yard manure FYM 15 t ha $), T 3\left(V_{l}(\mathrm{NOH}-15)+\right.$ Farm yard manure FYM 25 t ha $), T_{4}\left(V_{2}(S O N A L)\right.$ without FYM $), T_{5}\left(V_{2}(S O N A L)+\right.$ Farm yard manure FYM 15 t /ha $), T_{6}\left(V_{2}(S O N A L)+\right.$ Farm yard manure FYM $25 \mathrm{t} / \mathrm{ha}), \mathrm{T}_{7}\left(\mathrm{~V}_{3}(\mathrm{OH}-2324)\right.$ without $\left.\mathrm{FYM}\right), T_{8}\left(V_{3}(\mathrm{OH}-2324)+\right.$ Farm yard manure FYM $\left.15 \mathrm{t} / \mathrm{ha}\right)$ and $T_{9}\left(V_{3}\right.$ $(\mathrm{OH}-2324)+$ Farm yard manure FYM $25 \mathrm{t} / \mathrm{ha})$. The minimum Days to germination of seed in different okra treatments (3.68) was with treatment T5 (SONAL+FYM 15 tone/ha), The maximum T.S.S. $\left({ }^{0}\right.$ Brix) was recorded in the $T_{6}$ was (2.84), the maximum number of leaves was (49.35), The maximum number of branches was (2.80), The maximum average number of fruit per plant was (23.15), The maximum average Fresh weight of fruit was $(12.43 \mathrm{~g})$, The maximum fruit yield per plant was $(287.61 \mathrm{~g})$ the maximum Average fruit yield per hectare was $(16.25 \mathrm{t} / \mathrm{ha})$ The maximum ascorbic acid was $(15.58 \mathrm{mg} / 100 \mathrm{~g})$, maximum plant height was $(127.6 \mathrm{~cm})$, and were produced by the treatment $\left(T_{9}\right)(\mathrm{OH}-2324+25$ t/ha FYM $)$, It was the best treatment for growth and yield of okra Key word: Okra, Abelmoschus esculantus L. Monech, FYM, growth, yield and fruits quality
\end{abstract}

\section{Introduction}

Okra(Abelmoschus esculentus L Moench) belongs to the family Malvaceae, ,having chromosome number $(2 n)=130$. and it is commonly known as bhindi in India, krajiab kheaw in Thailand, okra plant, ochro, okoro, quimgombo, quingumbo, gombo,kopi arab, kacang bendi and bhindi in South Eas Asia. However, in Middle East it is known as bamia, bamya or bamieh and gumbo in Southern USA, and lady's finger in England (Ndunguru \& Rajabu 2004). Its tender green fruits are used as a vegetable and are generally marketed in fresh state, but sometime in canned or dehydrated form. Nutritive value varies in different cultivars and depending upon the agro - climate condition, Okra contains proteins, carbohydrates and vitamin C (Gopalan et al. 2007) and plays a vital role in human diet (Kahlon et al. 2007). Consumption of young immature okra pods is important as fresh fruits, and it can be consumed in different forms. Fruits can be boiled, fried or cooked (Akintoye $\boldsymbol{e t}$ al. 2011). The composition of okra pods per $100 \mathrm{~g}$ edible portion $(81 \%$ of the product as purchased, ends trimmed) is: water $88.6 \mathrm{~g}$, energy $144.00 \mathrm{~kJ}$ ( $36 \mathrm{kcal}$ ), protein $2.10 \mathrm{~g}$, carbohydrate $8.20 \mathrm{~g}$, fat $0.20 \mathrm{~g}$, fibre $1.70 \mathrm{~g}, \mathrm{Ca} 84.00 \mathrm{mg}, \mathrm{P} 90.00 \mathrm{mg}$, Fe $1.20 \mathrm{mg}$, $\beta$-carotene $185.00 \mu \mathrm{g}$, riboflavin $0.08 \mathrm{mg}$, thiamin $0.04 \mathrm{mg}$, niacin $0.60 \mathrm{mg}$, ascorbic acid $47.00 \mathrm{mg}$. The composition of okra leaves per $100 \mathrm{~g}$ edible portion is: water $81.50 \mathrm{~g}$, energy $235.00 \mathrm{~kJ}(56.00 \mathrm{kcal})$, protein $4.40 \mathrm{~g}$, fat $0.60 \mathrm{~g}$, carbohydrate $11.30 \mathrm{~g}$, fibre $2.10 \mathrm{~g}, \mathrm{Ca}$ $532.00 \mathrm{mg}, \mathrm{P} 70.00 \mathrm{mg}, \mathrm{Fe} 0.70 \mathrm{mg}$, ascorbic acid $59.00 \mathrm{mg}$, $\beta$-carotene $385.00 \mu \mathrm{g}$, thiamin $0.25 \mathrm{mg}$, riboflavin $2.80 \mathrm{mg}$, niacin $0.20 \mathrm{mg}$ (Varmudy 2011). Carbohydrates are mainly present in the form of mucilage ( Kumar et al. 2009). That of young fruits consists of long chain molecules with a molecular weight of about 170,000 made up of sugar units and amino acids. The main components are galactose $(25 \%)$, rhamnose $(22 \%)$, galacturonic acid (27\%) and amino acids (11\%). The mucilage is highly soluble in water. Its solution in water has an intrinsic viscosity value of about $30 \%$ Farmers need adequate resources to replenish soil fertility and maintain the productivity of soil. Really, the green revolution has popularized the use of chemical fertilizers to achieve higher productivity. But due to continuous and indiscriminate use of fertilizers, the natural fertility of soil has been lost and this activity has contaminated our soil, water and food. Therefore farmers are in need of searching alternative to replace the chemical fertilizers. In recent days, the use of organic inputs like FYM, compose vermicompost etc.is becoming popular in the world wide. There is a need of effective technology to deal with disposal of wastes which continues to be a challenge as population increases. organic manure has been identified as one of the potential processes in managing waste, since it is a natural process, cost effective and required only shorter duration. The application of organic manure helps in increasing the organic matter content of the soil, in maintaining soil natural productivity (Anil Kumar et al., 2011).

Keeping the above facts and importance of the work in the mind, following objective were taken : 


\section{Objectives:}

1. To find out the most suitable treatment for growth, yield and fruit quality of okra.

2. To work out the economics of various treatments.

\section{Materials And Methods}

The present investigation on growth, yield and quality of okra was carried in the Department of Horticulture, Allahabad Agricultural Institute - Deemed University, Allahabad during the winter (Rabi) season of 2012-2013. The objective was to find put the best combination of farm yard manure (FYM) growth and yield of okra for this region

\section{Treatment details}

The following treatments were applied:

\begin{tabular}{|l|l|}
\hline $\mathrm{T}_{1}$ & $\mathrm{~V}_{1}(\mathrm{NOH}-15)+\mathrm{RDF}$ \\
\hline $\mathrm{T}_{2}$ & $\mathrm{~V}_{1}(\mathrm{NOH}-15)+\mathrm{Farm}$ yard manure $(\mathrm{FYM}) 15 \mathrm{t} / \mathrm{ha}+\mathrm{RDF}$ \\
\hline $\mathrm{T}_{3}$ & $\mathrm{~V}_{1}(\mathrm{NOH}-15)+$ Farm yard manure $(\mathrm{FYM}) 25 \mathrm{t} / \mathrm{ha}+\mathrm{RDF}$ \\
\hline $\mathrm{T}_{4}$ & $\mathrm{~V}_{2}($ SONAL $)+\mathrm{RDF}$ \\
\hline $\mathrm{T}_{5}$ & $\mathrm{~V}_{2}($ SONAL) + Farm yard manure $(\mathrm{FYM}) 15 \mathrm{t} / \mathrm{ha}+\mathrm{RDF}$ \\
\hline $\mathrm{T}_{6}$ & $\mathrm{~V}_{2}($ SONAL) + Farm yard manure $(\mathrm{FYM}) 25 \mathrm{t} / \mathrm{ha}+\mathrm{RDF}$ \\
\hline $\mathrm{T}_{7}$ & $\mathrm{~V}_{3}(\mathrm{OH}-2324)+\mathrm{RDF}$ \\
\hline $\mathrm{T}_{8}$ & $\mathrm{~V}_{3}(\mathrm{OH}-2324)+$ Farm yard manure $(\mathrm{FYM}) 15 \mathrm{t} / \mathrm{ha}+\mathrm{RDF}$ \\
\hline $\mathrm{T}_{9}$ & $\mathrm{~V}_{3}(\mathrm{OH}-2324)+$ Farm yard manure $(\mathrm{FYM}) 25 \mathrm{t} / \mathrm{ha}+\mathrm{RDF}$ \\
\hline
\end{tabular}

The fertilizer was applied a basal dose of $100 \mathrm{~kg} \mathrm{~N}, 60 \mathrm{~kg} \mathrm{P}_{2} \mathrm{O}_{5}$ and $50 \mathrm{~kg} \mathrm{~K} \mathrm{~K}_{2} \mathrm{O}$ /ha. One third of nitrogen of entire quantity of $\mathrm{P}$ and $\mathrm{K}$ was applied prior to sowing remaining of nitrogen was applied in two splits at 30 and 60 Days after sowing. FYM was applied in the soil before two weeks from sowing according to the treatments. All the treatments were given the same dose of NPK fertilizer, but FYM did not apply in T1,T4,T7 and it was applied 15 ton/ha in T2,T5,T8 and 25 ton /ha in T3,T6.T9.

\section{Days to germination of seed in different okra treatments :-}

\section{Results and Discussion}

The statistically analyzed data are presented in table 1 the results indicated that all the treatments showed significant differences in relation to days taken to germination. The minimum days (3.68) to germination were recorded in treatment T5 (SONAL+FYM 15 tone/ha), followed by 3.77 days in treatment T6 (SONAL+FYM 25 tone/ha).The maximum days to germination was noticed in treatment $\mathrm{T} 1$ (NOH-15 without FYM) was 4.65 days.

\section{Plant height (cm) at 30, 60 and 90 DAS.}

Plant height was measured at 30,60 and 90 DAS to effect of FYM on growth of plant height. The statistically analyzed data are presented in table 2 , results showed that all the treatments in this experiment produced considerable amount of changes in plant height. At 30 DAS out of 9 treatments studied, maximum plant height $(24.26 \mathrm{~cm})$ was with OH-2324 +25 tone/ha from FYM followed by SONAL+25 tone/ha from FYM $(23.82 \mathrm{~cm})$, which were statistically at par. The minimum plant height was with NOH-15 without FYM (21.23 $\mathrm{cm}$ ). At 60 DAS, out of 9 treatments studied treatment T5 (SONAL+FYM 15 tone/ha) followed by SONAL +25 tone/ha FYM $(82.25 \mathrm{~cm})$, which were statistically at par. The minimum plant height was with $\mathrm{NOH}-15$ without FYM $(66.50 \mathrm{~cm})$.At 90 Days similar trend was similar trend was noticed, where maximum plant height (127.6 $\mathrm{cm})$ was with $\mathrm{OH}-2324+25$ tone/ha FYM, followed by sonal+25 tone/ha FYM $(118.90 \mathrm{~cm})$, which were statistically at par. The minimum plant height was with NOH-15 without FYM $(100.12 \mathrm{~cm})$.

\section{Number of leaves per plant at 30,60 and 90 DAS.}

It is evident from table 3 there was significant difference between treatment at 30,60 and 90 DAS for number of leaves per treatment.At 30 DAS , the maximum number of leaves was recorded with SONAL+25 tone/ha FYM (13.67) followed by OH-2324 + 25 tone/ha FYM (13.41) followed by NOH- $15+25$ tone/ha FYM (12.76) which were at par with each okra. The minimum number of level was recorded with $\mathrm{NOH}-15$ without FYM (10.28).At 60 DAS, the maximum number of leaves was observed under treatment $\mathrm{OH}-2324+25$ tone/ha FYM (41.29) followed by SONAL+25 tone/ha FYM (40.05) which were at par with each Okra. The minimum number of level was recorded with NOH-15 without FYM (34.18). At 90 DAS ,the maximum number of leaves was recorded with treatment of 9 (49.35) followed by treatment of 6 (48.14). The minimum leaved per treatment was observed under treatment NOH-15 without FYM (42.06). However, as far as number of leaves are concerned maximum of leaves was with treatment $\mathrm{OH}-2324+25$ tone/ha FYM. 


\section{Number of branches per treatment at 60 and 90 DAS :-}

The statistically analyzed data are presented in table 4 indicated that all the treatment showed the significant difference in relation to number of branch. The number of branches per treatment was measured at 60 and 90 DAS to effect of FYM on growth of branches. There was changes in the number of branches at 60 and 90 DAS. The maximum number of branches was recorded with OH-2324 +25 tone/ha FYM $(2.60)$, followed by T6 (2.40) which were at par with each Okra and minimum with $\mathrm{T}_{1}+\mathrm{T}_{4}(1.80)$. At 90 DAS , The maximum number of branches was recorded with T9 $(\mathrm{OH}-2324+25$ tone/ha FYM $(2.80)$, followed by T6 (2.70) which were at par with each Okra and minimum with $\mathrm{T}_{1}+\mathrm{T}_{4}(2.10)$.

\section{Average number of fruit per plant:-}

Analysis of data presented in the table 5 revealed that all treatments showed significant (at 5\% level) result in the case of number of fruits per plant. Number of fruits per plant was maximum in the T9 (23.15), followed by T6 (21.57) which were at par with each okra. The minimum (16.04) Number fruits per plant was observed in T1 (NOH-15 without FYM) .Similar results were also reported by Singh and Jain (2002) .

\section{Average Fresh weight of fruit (g) .}

Statistical analysis of the data are presented in table 5, This showed that there was significant differences among the treatments of okra.The treatment the highest fruit weight was recorded with $\mathrm{T} 9(\mathrm{OH}-$ $2324+25 \mathrm{t} / \mathrm{ha}$ FYM $)(12.43 \mathrm{~g})$ followed by T6(SONAL $+25 \mathrm{t} / \mathrm{ha}$ FYM) $(12.23 \mathrm{~g})$ which were at par with each okra. The minimum T1( NOH-15 without FYM) (10.85 g). Mohapatra et al.(2007) reported more or less similar findings in his experiment

\section{Average fruit yield per plant (g)}

Analysis of data presented in table 6 revealed that there were significant difference among the treatment in the yielding Capacity per plant.The fruit yield per plant was maximum in $\mathrm{T} 9(\mathrm{OH}-2324+25 \mathrm{t} / \mathrm{ha}$ FYM) $(287.61 \mathrm{~g})$ followed by T6( SONAL $+25 \mathrm{t} / \mathrm{ha} \mathrm{FYM})(263.80 \mathrm{~g})$ and the minimum (174.06 g) fruit yield per plant was observed in theT1( NOH-15 without FYM).These findings are reported by Muhammad $\boldsymbol{e t}$ al.(2001) Average fruit yield per hectare (t):-

Analysis of the data presented in table 6 revealed that there were significant differences among the treatments in the yielding capacity per unit area.The fruit yield per hectare was maximum in T9 $(\mathrm{OH}-2324$ +FYM $25 \mathrm{t} / \mathrm{ha}$ ) where was $(16.25 \mathrm{t} / \mathrm{ha})$ followed by T6(SONAL + FYM $25 \mathrm{t} / \mathrm{ha})$ where was $(14.91 \mathrm{t} / \mathrm{ha})$ and the minimum ( $9.84 \mathrm{t} / \mathrm{ha}$ ) fruit yield per hectare was observed in T1 ( NOH -15 without FYM). These findings are in close conformity with the results reported by Singh and Jain (2002).

\section{T.S.S ( ${ }^{0}$ Brix):-}

The statistical analyzed data presented in table 7 in revealed that all the treatments had significant differences in the case of average T.S.S.\% of fruit. The maximum T.S.S. $\left({ }^{0}\right.$ Brix) was recorded in the SONAL + FYM (25 tone/ha) was (2.84), followed by OH-2324+FYM (25 tone/ha) was (2.78) which were at par with each Okra. The minimum T.S.S. $\left({ }^{0} \mathrm{Brix}\right)$ was found in NOH-15 without FYM (2.52).

\section{Ascorbic acid (mg/100mg):-}

The statistical analyzed data presented in Table 7 revealed that all the treatments had significant differences in the case of ascorbic acid. The maximum ascorbic acid was recorded in OH-2324+FYM (25 tone / ha) $(15.58 \mathrm{mg} / 100 \mathrm{~g})$, followed by OH-2324+FYM (15tone/ha) was $(15.52 \mathrm{mg} / 100 \mathrm{~g})$. which were at par with each okra. The minimum ascorbic acid was found in NOH-15 without FYM was (12.83 mg /100).

\section{Discussion}

The difference in growth, yield and fruits quality of okra (Abelmoschus esculentus. L Moench) may be due to difference in their genetic and Organic manure have the capability of supplying a range of nutrients and improving the physical and biological properties of the soil (Chaterjee et al., 2005) which lead to increased up take of NPK and reduce the nutrient losses, improving the fertilizer use efficiency thus increasing the soil nutrient availability (Gruhn et al 2000). Organic manure such as Farm yard manure (FYM) refers to decomposed mixture of dug and urine of farm animals along with the litter and left over material from roughages or fodder fed the cattle. On the average well rotted FYM contain ( N\% $0.50, \mathrm{P} \% 0.24, \mathrm{~K} \% 0.53, \mathrm{Fe}$ $251.3 \mathrm{mg} / \mathrm{kg}, \mathrm{Zn} 135 \mathrm{mg} / \mathrm{kg}, \mathrm{Mg} \% 0.18$, Ca \% $0.22, \mathrm{Mn} 181.2 \mathrm{mg} / \mathrm{kg}, \mathrm{Cu} 22.1 \mathrm{mg} / \mathrm{kg}, \mathrm{S} \% 0.23$ ) (Vasant , 2010 ). Organic manures are very important for plant and healthy human and create of clean environmental which is Resulted in high yield of okra Further, application of organic manure which might have accelerated the vigorous growth, increase of yield of okra plant. In view of the experimental results obtained during the present investigation, treatment $\mathrm{T}_{9}(\mathrm{OH}-2324+$ Farm yard manure (FYM) $25 \mathrm{t} / \mathrm{ha}$ ) was 
found most suitable treatment for growth, yield and economic returns for cultivation of okra under the agroclimatic condition of Allahabad. However, since this is based on one year experiment, further trials may be needed to substantiate the results.

Table 1 : Days to germination of seed in different okra treatments .

\begin{tabular}{|c|c|}
\hline Treatments & $\begin{array}{c}\text { Days to } 50 \% \text { germination in different } \\
\text { okra treatments }\end{array}$ \\
\hline $\mathrm{T}_{1}-\mathrm{NOH}-15+\mathrm{RDF}$ & 4.65 \\
\hline $\mathrm{T}_{2}$ - NOH-15+ Farm yard manure (FYM) 15 tone $/ \mathrm{ha}+\mathrm{RDF}$ & 4.2 \\
\hline $\mathrm{T}_{3}$ - NOH-15+ Farm yard manure (FYM) 25 tone $/$ ha + RDF & 4.33 \\
\hline $\mathrm{T}_{4}-\mathrm{SONAL}+\mathrm{RDF}$ & 4.42 \\
\hline $\mathrm{T}_{5}-\mathrm{SONAL}+$ Farm yard manure $(\mathrm{FYM}) 15$ tone $/ \mathrm{ha}+\mathrm{RDF}$ & 3.68 \\
\hline $\mathrm{T}_{6}$ - SONAL + Farm yard manure $(\mathrm{FYM}) 25$ tone $/ \mathrm{ha}+\mathrm{RDF}$ & 3.77 \\
\hline $\mathrm{T}_{7^{-}} \mathrm{OH}-2324+\mathrm{RDF}$ & 4.54 \\
\hline $\mathrm{T}_{8^{-}} \mathrm{OH}-2324+$ Farm yard manure $(\mathrm{FYM}) 15$ tone $/ \mathrm{ha}+\mathrm{RDF}$ & 4.2 \\
\hline $\mathrm{T}_{9-} \mathrm{OH}-2324+$ Farm yard manure (FYM) 25 tone $/ \mathrm{ha}+\mathrm{RDF}$ & 3.98 \\
\hline F- test & $\mathrm{S}$ \\
\hline S. Ed. $( \pm)$ & 0.17 \\
\hline C. D. $(P=0.05)$ & 0.36 \\
\hline
\end{tabular}

Table 2 : Plant height (cm) at 30, 60 and 90 DAS.

\begin{tabular}{|c|c|c|c|}
\hline \multirow{2}{*}{ Treatments } & \multicolumn{3}{|c|}{ Plant height $(\mathrm{cm})$} \\
\hline & $30 \mathrm{DAS}$ & 60DAS & $60 \mathrm{DAS}$ \\
\hline $\mathrm{T}_{1}-\mathrm{NOH}-15+\mathrm{RDF}$ & 21.23 & 66.5 & 100.12 \\
\hline $\mathrm{T}_{2}-\mathrm{NOH}-15+$ Farm yard manure $(\mathrm{FYM}) 15$ tone $/ \mathrm{ha}+\mathrm{RDF}$ & 22.04 & 74.95 & 103.33 \\
\hline $\mathrm{T}_{3}-\mathrm{NOH}-15+$ Farm yard manure $(\mathrm{FYM}) 25$ tone $/ \mathrm{ha}+\mathrm{RDF}$ & 23.5 & 80.33 & 115.57 \\
\hline $\mathrm{T}_{4}-\mathrm{SONAL}+\mathrm{RDF}$ & 21.84 & 68.92 & 100.87 \\
\hline $\mathrm{T}_{5^{-}}$SONAL + Farm yard manure $(\mathrm{FYM}) 15$ tone $/ \mathrm{ha}+\mathrm{RDF}$ & 22.67 & 76.67 & 107.32 \\
\hline $\mathrm{T}_{6-}-\mathrm{SONAL}+$ Farm yard manure $(\mathrm{FYM}) 25$ tone $/ \mathrm{ha}+\mathrm{RDF}$ & 23.82 & 82.25 & 118.9 \\
\hline $\mathrm{T}_{7-} \mathrm{OH}-2324+\mathrm{RDF}$ & 21.99 & 71.35 & 101.22 \\
\hline $\mathrm{T}_{8^{-}} \mathrm{OH}-2324+$ Farm yard manure $(\mathrm{FYM}) 15$ tone $/ \mathrm{ha}+\mathrm{RDF}$ & 23.13 & 79.18 & 111.43 \\
\hline $\mathrm{T}_{9}-\mathrm{OH}-2324+$ Farm yard manure (FYM) 25 tone $/ \mathrm{ha}+\mathrm{RDF}$ & 24.26 & 86.06 & 127.6 \\
\hline F- test & $\mathrm{S}$ & $\mathrm{S}$ & $\mathrm{S}$ \\
\hline S. Ed. $( \pm)$ & 0.8 & 1.4 & 1.19 \\
\hline C. D. $(P=0.05)$ & 1.7 & 2.98 & 2.53 \\
\hline
\end{tabular}

Table 3 : Number of leaves per plant at 30,60 and 90 DAS.

\begin{tabular}{|c|c|c|c|}
\hline \multirow{2}{*}{ Treatments } & \multicolumn{3}{|c|}{ No of leaves } \\
\hline & 30DAS & 60DAS & 60DAS \\
\hline $\mathrm{T}_{1}-\mathrm{NOH}-15+\mathrm{RDF}$ & 10.28 & 34.18 & 42.06 \\
\hline $\mathrm{T}_{2}-\mathrm{NOH}-15+$ Farm yard manure $(\mathrm{FYM}) 15$ tone $/ \mathrm{ha}+\mathrm{RDF}$ & 11.84 & 37.71 & 44.41 \\
\hline $\mathrm{T}_{3}-\mathrm{NOH}-15+$ Farm yard manure $(\mathrm{FYM}) 25$ tone $/ \mathrm{ha}+\mathrm{RDF}$ & 12.76 & 39.27 & 47.77 \\
\hline $\mathrm{T}_{4}-\mathrm{SONAL}+\mathrm{RDF}$ & 10.91 & 35.55 & 42.8 \\
\hline $\mathrm{T}_{5^{-}} \mathrm{SONAL}+$ Farm yard manure $(\mathrm{FYM}) 15$ tone $/ \mathrm{ha}+\mathrm{RDF}$ & 12.08 & 38.07 & 45.29 \\
\hline $\mathrm{T}_{6}-\mathrm{SONAL}+$ Farm yard manure $(\mathrm{FYM}) 25$ tone $/ \mathrm{ha}+\mathrm{RDF}$ & 13.67 & 40.05 & 48.14 \\
\hline $\mathrm{T}_{7-} \mathrm{OH}-2324+\mathrm{RDF}$ & 11.45 & 36.68 & 43.2 \\
\hline $\mathrm{T}_{8^{-}} \mathrm{OH}-2324+$ Farm yard manure $(\mathrm{FYM}) 15$ tone $/ \mathrm{ha}+\mathrm{RDF}$ & 12.36 & 38.3 & 46.11 \\
\hline $\mathrm{T}_{9}-\mathrm{OH}-2324+$ Farm yard manure (FYM) 25 tone $/$ ha $+\mathrm{RDF}$ & 13.41 & 41.29 & 49.35 \\
\hline F- test & $\mathrm{S}$ & $\mathrm{S}$ & $\mathrm{S}$ \\
\hline S. Ed. $( \pm)$ & 0.49 & 1.06 & 0.86 \\
\hline C. D. $(P=0.05)$ & 1.04 & 2.25 & 1.83 \\
\hline
\end{tabular}

Table 4 : Number of branches per treatment at 60 and 90 DAS .

\begin{tabular}{|c|c|c|}
\hline \multirow{2}{*}{ Treatments } & \multicolumn{2}{|c|}{ No of branches } \\
\hline & 60 DAS & 90 DAS \\
\hline $\mathrm{T}_{1}-\mathrm{NOH}-15+\mathrm{RDF}$ & 1.8 & 2.1 \\
\hline $\mathrm{T}_{2}-\mathrm{NOH}-15+$ Farm yard manure $(\mathrm{FYM}) 15$ tone $/ \mathrm{ha}+\mathrm{RDF}$ & 2 & 2.2 \\
\hline $\mathrm{T}_{3}$ - NOH-15+ Farm yard manure (FYM) 25 tone /ha +RDF & 2.3 & 2.5 \\
\hline $\mathrm{T}_{4}-\mathrm{SONAL}+\mathrm{RDF}$ & 1.8 & 2.1 \\
\hline
\end{tabular}




\begin{tabular}{|c|c|c|} 
& 2.1 & 2.3 \\
\hline $\mathrm{T}_{5}$ - SONAL + Farm yard manure (FYM) 15 tone $/ \mathrm{ha}+\mathrm{RDF}$ & 2.4 & 2.7 \\
\hline $\mathrm{T}_{6}$ SONAL + Farm yard manure (FYM) 25 tone $/ \mathrm{ha}+\mathrm{RDF}$ & 1.9 & 2.2 \\
\hline $\mathrm{T}_{7^{-}} \mathrm{OH}-2324+\mathrm{RDF}$ & 2.2 & 2.4 \\
\hline $\mathrm{T}_{8^{-}} \mathrm{OH}-2324+$ Farm yard manure (FYM) 15 tone $/ \mathrm{ha}+\mathrm{RDF}$ & 2.6 & 2.8 \\
\hline $\mathrm{T}_{9^{-}} \mathrm{OH}-2324+$ Farm yard manure (FYM) 25 tone $/ \mathrm{ha}+\mathrm{RDF}$ & $\mathrm{S}$ & $\mathrm{S}$ \\
\hline $\mathrm{F}-$ test & 0.09 & 0.07 \\
\hline S. Ed. $( \pm)$ & 0.19 & 0.15 \\
\hline C. D. $(\mathrm{P}=0.05)$ & & \\
\hline
\end{tabular}

Table 5: Average number of fruit per plant and Average Fresh weight of fruit (g).

\begin{tabular}{|c|c|c|}
\hline Treatments & No. of fruits & Weight of fruit (g) \\
\hline $\mathrm{T}_{1}-\mathrm{NOH}-15+\mathrm{RDF}$ & 16.04 & 10.85 \\
\hline $\mathrm{T}_{2}-\mathrm{NOH}-15+$ Farm yard manure $(\mathrm{FYM}) 15 \mathrm{t} / \mathrm{ha}+\mathrm{RDF}$ & 19.00 & 11.49 \\
\hline $\mathrm{T}_{3}-\mathrm{NOH}-15+$ Farm yard manure $(\mathrm{FYM}) 25 \mathrm{t} / \mathrm{ha}+\mathrm{RDF}$ & 21.30 & 12.18 \\
\hline $\mathrm{T}_{4}-\mathrm{SONAL}+\mathrm{RDF}$ & 16.11 & 11.21 \\
\hline $\mathrm{T}_{5^{-}}$SONAL + Farm yard manure $(\mathrm{FYM}) 15 \mathrm{t} / \mathrm{ha}+\mathrm{RDF}$ & 19.78 & 11.62 \\
\hline $\mathrm{T}_{6}-\mathrm{SONAL}+$ Farm yard manure $(\mathrm{FYM}) 25 \mathrm{t} / \mathrm{ha}+\mathrm{RDF}$ & 21.57 & 12.23 \\
\hline $\mathrm{T}_{7-} \mathrm{OH}-2324+\mathrm{RDF}$ & 17.80 & 11.27 \\
\hline $\mathrm{T}_{8^{-}} \mathrm{OH}-2324+$ Farm yard manure $(\mathrm{FYM}) 15 \mathrm{t} / \mathrm{ha}+\mathrm{RDF}$ & 21.20 & 11.87 \\
\hline $\mathrm{T}_{9-} \mathrm{OH}-2324+$ Farm yard manure (FYM) $25 \mathrm{t} / \mathrm{ha}+\mathrm{RDF}$ & 23.15 & 12.43 \\
\hline F- test & $\mathrm{S}$ & $\mathrm{S}$ \\
\hline S. Ed. $( \pm)$ & 0.66 & 0.44 \\
\hline C. D. $(P=0.05)$ & 1.41 & 0.93 \\
\hline
\end{tabular}

Table 6 : Average fruit yield per plant (g) and Average fruit yield per hectare (t).

\begin{tabular}{|c|c|c|}
\hline Treatments & $\begin{array}{l}\text { Yield of plant } \\
\text { (g) }\end{array}$ & $\begin{array}{c}\text { Total yield } \\
\text { (t/ha) }\end{array}$ \\
\hline $\mathrm{T}_{1}-\mathrm{NOH}-15+\mathrm{RDF}$ & 174.06 & 9.84 \\
\hline $\mathrm{T}_{2}-\mathrm{NOH}-15+$ Farm yard manure $(\mathrm{FYM}) 15 \mathrm{t} / \mathrm{ha}+\mathrm{RDF}$ & 218.24 & 12.33 \\
\hline $\mathrm{T}_{3}-\mathrm{NOH}-15+$ Farm yard manure $(\mathrm{FYM}) 25 \mathrm{t} / \mathrm{ha}+\mathrm{RDF}$ & 259.33 & 14.66 \\
\hline $\mathrm{T}_{4}-\mathrm{SONAL}+\mathrm{RDF}$ & 180.59 & 10.21 \\
\hline $\mathrm{T}_{5^{-}}$SONAL + Farm yard manure (FYM) $15 \mathrm{t} / \mathrm{ha}+\mathrm{RDF}$ & 229.85 & 12.99 \\
\hline $\mathrm{T}_{6}-\mathrm{SONAL}+$ Farm yard manure (FYM) $25 \mathrm{t} / \mathrm{ha}+\mathrm{RDF}$ & 263.80 & 14.91 \\
\hline $\mathrm{T}_{7}-\mathrm{OH}-2324+\mathrm{RDF}$ & 200.49 & 11.33 \\
\hline $\mathrm{T}_{8^{-}} \mathrm{OH}-2324+$ Farm yard manure $(\mathrm{FYM}) 15 \mathrm{t} / \mathrm{ha}+\mathrm{RDF}$ & 251.88 & 14.24 \\
\hline $\mathrm{T}_{9^{-}} \mathrm{OH}-2324+$ Farm yard manure (FYM) $25 \mathrm{t} / \mathrm{ha}+\mathrm{RDF}$ & 287.61 & 16.25 \\
\hline F- test & $\mathrm{S}$ & $\mathrm{S}$ \\
\hline S. Ed. $( \pm)$ & 9.95 & 0.56 \\
\hline C. D. $(P=0.05)$ & 21.10 & 1.19 \\
\hline
\end{tabular}

Table 7 : T.S.S. and Ascorbic acid.

\begin{tabular}{|c|c|c|}
\hline Treatments & T.S.S. & $\begin{array}{c}\text { Ascorbic Acid (mg } \\
/ \mathbf{1 0 0 g})\end{array}$ \\
\hline $\mathrm{T}_{1}-\mathrm{NOH}-15+\mathrm{RDF}$ & 2.52 & 12.83 \\
\hline $\mathrm{T}_{2}-\mathrm{NOH}-15+$ Farm yard manure $(\mathrm{FYM}) 15$ tone $/ \mathrm{ha}+\mathrm{RDF}$ & 2.55 & 13.35 \\
\hline $\mathrm{T}_{3}-\mathrm{NOH}-15+$ Farm yard manure $(\mathrm{FYM}) 25$ tone $/ \mathrm{ha}+\mathrm{RDF}$ & 2.75 & 14.37 \\
\hline $\mathrm{T}_{4}-\mathrm{SONAL}+\mathrm{RDF}$ & 2.58 & 13.11 \\
\hline $\mathrm{T}_{5}-\mathrm{SONAL}+$ Farm yard manure $(\mathrm{FYM}) 15$ tone $/ \mathrm{ha}+\mathrm{RDF}$ & 2.71 & 14.12 \\
\hline $\mathrm{T}_{6^{-}} \mathrm{SONAL}+$ Farm yard manure $(\mathrm{FYM}) 25$ tone $/ \mathrm{ha}+\mathrm{RDF}$ & 2.84 & 15.45 \\
\hline $\mathrm{T}_{7}-\mathrm{OH}-2324+\mathrm{RDF}$ & 2.63 & 13.28 \\
\hline $\mathrm{T}_{8^{-}} \mathrm{OH}-2324+$ Farm yard manure $(\mathrm{FYM}) 15$ tone $/ \mathrm{ha}+\mathrm{RDF}$ & 2.66 & 15.52 \\
\hline $\mathrm{T}_{9}$ - $\mathrm{OH}-2324+$ Farm yard manure $(\mathrm{FYM}) 25$ tone $/ \mathrm{ha}+\mathrm{RDF}$ & 2.78 & 15.58 \\
\hline F- test & $\mathrm{S}$ & $\mathrm{S}$ \\
\hline S. Ed. $( \pm)$ & 0.05 & 0.16 \\
\hline C. D. $(P=0.05)$ & 0.1 & 0.34 \\
\hline
\end{tabular}




\section{Reference}

[1]. Akintoye HA, Adepayo AG, Aina OO (2011): Growth and yield response of okra intercropped winth lieu mulches. Asion J. Agric. Res. 5:146-153.

[2]. Anil kumar D. Talageri , J.Narayana and Y.P. Shilpshree. (2011). A Comparative Assessment of Organic manures and Inorganic Fertilizers on Okra (Abelmoschus esculentus) International Journal of Life Sciences 2(1):53-59.

[3]. Chaterjee, B.;Ghanti,P.;Thapa,U and Tripathy,P. (2005). Effect of organic nutrition in spro broccoli (Brassica aleraceae var. italica plenck). Vegetable Science. 33 (1): 51-54.

[4]. Gopalan. C., Rama sastri . B.V. and Balasubramanian. S., (2007). Nutritive Value of Indian Foods, Published by Natritive Istitute of Natrition (NIN), ICMR.

[5]. Gruhn,p.; Goletti,F and Yudelman,M.(2000).Integrated Nutrient Management, Soil Fertility and Sustainable Agriculture. Food, Agriculture, and the Environment Discussion:1-31.

[6]. Kahlon TS, Chapman MH, Smith G E (2007): In vitro binding of bile acids by okra beets asparagus eggplant turnip green beans Carrots and Cauliflower. Food Chem. 103:676-780.

[7]. Kumar R, Patil MB, Patil SR, Paschapur MS (2009): Evaluation of Abelmoschus esculentus mucilage as suspending agent in paracetamol suspension. Asion J. Agric. Res. 1:658-665.

[8]. Mohapatra, M. R.; Acharyya, P. and Sengupta, S.(2007). Variability and association analysis in okra. Indian Agriculture 51 (12): $17-26$.

[9]. Muhammad. A., Muhammad. S.M. and Mushtaq .(2001). Comparative study on the performance of some exotic okra. Inte. J. Agri. And Bio.3 (4): 423-425

[10]. Ndunguru J, Rajabu AC (2004): Effect of okra mosaic virus disease on the above ground .

[11]. Singh, D.K. and Jain, S.K. (2002). Performance of okra cultivars. Ann Res.Report.Submitted to D.E.S. Pantnager, Page: 3.

[12]. Varmudy V (2011): Markingsurvey need to boost okra exports. Department of economics, Vivekananda College, Puttur, Karnataka, India.

[13]. Vasant,M.G.(2010).Response of bell pepper to organic nutrition under different environments, Thesis submitted to the University of Agricultural Sciences, Dharwad in partial fulfillment of the requirements for the Degree of doctor of philosophy .

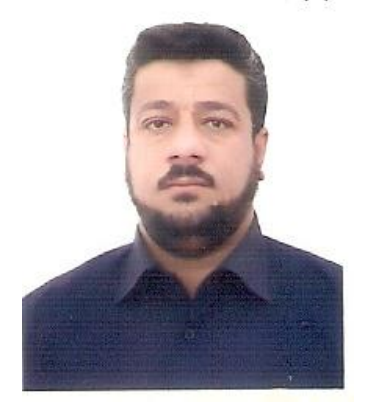

Hisham Aziz Amran

Iraq, 9/1/1976, Received his bachelor of Agriculture , horticulture , Baghdad university , Agriculture collage in Iraq in 1998 . He is Pursuing M.sc. agriculture, Department of Horticulture, Horticulture in SHIATS, Allahabad. He has experience for eleven Years with agriculture. Presently he is working as, Iraq ministry of Higher education, Karbala university , Agriculture Collage

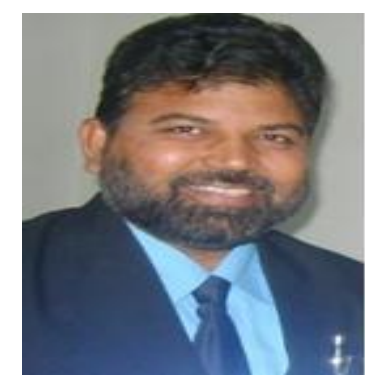

Prof. (Dr.) V. M Prasad Allahabad, 25/06/1961, Received his Bachelor of agriculture, horticulture Allahabad Agriculture Institute, Allahabad- India in 1983; He obtained his M.Sc.(Ag). degree in Ag. Horticulture, Allahabad Agriculture Institute, Allahabad- India in 1985. He completed his Ph.D horticulture of Kanpur University in 1995. He has published several research paper in the field of agriculture, horticulture. Presently he is working as Professor and Head of department of horticulture SHIATS Allahabad- India.

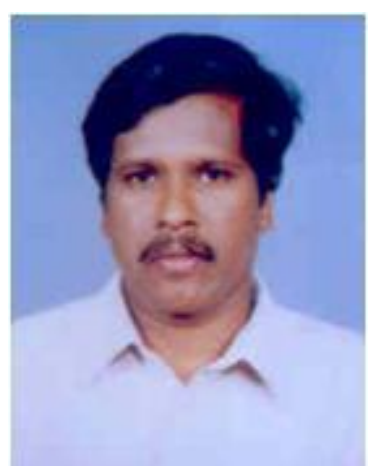

Dr. S. Saravanan Allahabad, 25/06/1970,Received his Bachelor of horticulture Tamil Nadu Agriculture

University India in 1994; He obtained his M.Sc. Horticulture, T.N.A.U.- India in 1998. He completed his Ph.D horticulture

of T.N.A.U. in 2001. He has published several research paper in the field of agriculture, horticulture. Presently he is working Associate Professor of department of horticulture SHIATS Allahabad 